\title{
A reassessment of E.H. Carr and the realist tradition: Britain, German- Soviet Relations and neoclassical realism
}

Keith Smith, University of Strathclyde

\begin{abstract}
E.H. Carr's connection to realism has increasingly been called into question. Revisionist literature has pointed to realism's narrow understanding of Carr and drawn from his wider body of work in order to problematize Carr's association with realism. Given that it overlooks two key texts produced by Carr, the revisionist literature is incomplete. Refocusing on Britain and German-Soviet Relations, especially the way in which they reflect ideas associated with the realist tradition, this paper demonstrates the continued traditional link between Carr and realism. Having done so, it considers the contemporary relevance of Carr's lesser known realist work. Drawing parallels between Britain and German-Soviet Relations and neoclassical realism, the paper contends that Carr's forgotten texts can serve as the foundation for a more classically orientated, European mode of neoclassical realism.
\end{abstract}

\section{Introduction}

For at least the last two decades, International Relations (IR) has undertaken what has been termed a historiographical turn (Bell, 2001). The reasons for this are relatively straightforward and documented elsewhere: following the end of the Cold War, if not before, the discipline's hegemonic truths became increasingly contested. Much of the work here has focused on destabilising our traditional understanding of the first great debate (e.g. Schmidt, 2012) in addition to presenting a more accurate and refined understanding of canonical, typically realist thinkers (e.g. Williams, 2007; Bell, 2009). In terms of the latter, much work 
has offered a more nuanced understanding of classical realist authors, seeking to challenge realism's colonisation of these texts and draw parallels with contemporary critical approaches (e.g. Behr and Molloy, 2013).

Aligned with this trend, a more specific literature has questioned the typical disciplinary understanding of E.H. Carr. This focus is understandable as E.H. Carr broadly and The Twenty Years' Crisis specifically (whether or not intentionally) played a pivotal role in the development of the discipline's historical narrative (Dunne et al, 1998). The revisionist literature, which will be discussed below, has increasingly questioned the orthodox depiction of Carr and his most (in)famous text by drawing attention to the texts produced by Carr in the interwar and postwar era. This literature is more incomplete than inaccurate, however, because it overlooks two texts, Britain and German-Soviet Relations, which were written by Carr in the same period. Utilising Haslam's (2002) tour de horizon of realist thought, this paper makes the case that a more authentic realism can be found in these overlooked texts. The analysis is subsequently extended by illustrating points of convergence and divergence between these lost texts and contemporary realist approaches, specifically neoclassical realism.

The discussion below draws from Steele's (2013, pp. 741-743) double movement of restoration and contemporary reconstruction. The former entails trying to restore a classical text as one would attempt (as much as is possible) to restore a building to its original form. The latter, in contrast, involves teasing out the implications of a classical text and bringing them to bear on contemporary scholarly debates. The paper begins by sketching out the revisionist turn and the manner in which it has reshaped our understanding of Carr broadly and The Twenty Years' Crisis specifically. Importantly, the revisionist literature's incompleteness - its oversight of Britain and German-Soviet Relations - is highlighted. This necessitates the second section, which, using a number of realist principles as focal points, 
restores Britain and German-Soviet Relations to the realist tradition. The third section then ponders on the relationship between Carr's lost work and neoclassical realism. It argues that Britain and German-Soviet Relations can exploit the transatlantic divide in terms of contemporary neoclassical realist work and serve as the foundation for a more classically orientated, European mode of neoclassical realism.

\section{Revisionism and The Twenty Years' Crisis}

Revisionist historiography is concerned with challenging taken-for-granted truths and conventions (Ashworth, 2014, p. 15). It entails digging 'deeper into the history [of IR]', which ultimately involves painting 'a picture that is far more textured, much more complicated, and altogether interesting, than the one we normally present to our first year students' (Cox, 2012, p. xiv). In terms of Carr and The Twenty Years' Crisis, this entails questioning his relationship to realism. Historically and conventionally Carr's relationship to realism has been affirmed. Thomson (1980), as an example, writes that Carr laid 'the foundations for political realism' (p. 69). Contemporary scholars reproduce this idea. As an example, Mearsheimer (2005) notes that Carr's attack on utopian intellectualism earned Carr 'his realist spurs' (p. 141). Revisionists question this understanding. Generally, the revisionist view can be distilled to two points: first, The Twenty Years' Crisis in particular has been misunderstood at the very least or, more nefariously, misrepresented; and second, Carr more widely has been mischaracterised because the traditional view has tended to reduce his contribution to The Twenty Years' Crisis instead of appreciating the breadth and depth of his writings on international affairs.

To take the latter point first, Wilson (2001) writes of a typically held view in the field that 'Carr's contribution to international relations begins and ends with The Twenty Years' Crisis', which is a view that Wilson terms 'damaging...not only for our understanding of his 
thought as a whole, but also our understanding of [The Twenty Years' Crisis] itself' (p. 125). Johnston (1967) and Evans (1975) were the first to broaden the typically held narrow view by disagreeing over the extent to which Carr's explanation for the breakdown of order was congruent across The Twenty Years' Crisis, Conditions of Peace and Nationalism and After. Howe (1994) followed suit by pointing to the evident critical edge underpinning these three texts. Subsequently Linklater (1997) showed the importance of a more expansive understanding of citizenship buttressing The Twenty Years' Crisis and Nationalism and After specifically. More extensive monographs followed by Jones (1998) and Haslam (2000) in which biographical details often overlooked were given fuller consideration. Cox's (2004) edited collection, which included contributions from specialists in IR, history and Sovietology, equally served as a reminder that Carr's thought was more extensive and indeed more interesting than the traditional view gave him credit for. And, more recently, work has sought to recover Carr's romantic biographical period (Nishimura, 2011), consider the ethical positions underlying his work (Molloy, 2013), reconsider Carr's historical understanding of the state (Kostagiannis, 2013) and stress the influence of Frankfurt critical theory on The Twenty Years' Crisis and What is History (Babík, 2013). Gone, in other words, is the traditional depiction of Carr; in its place is a more plural understanding, which is best captured in Wilson's (2001) depiction of Carr as a "'sort-ofRealist/Functionalist/Keynesian/Marxist-influenced/Proto-IR-Critical Theorist"” (p. 130).

The broadening of our understanding of Carr's contribution to IR has enhanced our understanding of his most (in)famous text, The Twenty Years' Crisis. In turn, the depiction of it as realism par excellence has been undermined. Booth (1991), as an example, concludes that the traditional depiction of it as an attack on utopianism 'failed to note [Carr's] uncertainty, his criticism of realism and his positive comments about utopianism' (p. 531). Likewise, Jones (1998) observes that familiarity with Carr and The Twenty Years' Crisis 'has 
gone hand in hand with deep confusion about the interpretation of his work' (p. 3). More scathingly, perhaps, Cox in his preface to the text's reissue suggests that its meaning was purposefully bent out of shape in order to legitimise a particular way of thinking about international affairs at the onset of the Cold War. In turn, it definitely came close to becoming 'the least understood book in the history of international relations' (Carr, 2001, p. xiii).

Whether the text's meaning was misconstrued or manipulated is not the concern here. What is clear, however, is that the text's progressive aspects make its relationship to the realist tradition problematic. Wilson (2012) defines progressive change as the 'belief that the world does not have to look the way that it does, and that through reason, courage, imagination and determination it is possible to arrive at a better way of being and living' ( $\mathrm{p}$. 135). In contrast to this hopeful outlook, realists 'can generally be counted on to take a pessimistic or "Augustinian" view of the behaviour of man or society or both in the conduct of international relations' (Haslam, 2002, p. 12). It is the former elements, as others have pointed out, which have been downplayed in the conventional understanding of Carr (Booth, 1991; Howe, 1994; Linklater, 1997).

Moreover, the conventional understanding of the text has typically focused on Carr's attack on the utopian tendency of neglecting of power (Mearsheimer, 2005, p. 140). This has helped conceal his attack on realism as determinism. Take the very first paragraph of the first edition's preface as an example. According to Carr (1946), it was 'written at a time when war was already casting its shadow on the world, but when all hope of averting it was not yet lost' (p. ix, my emphasis). The criticism that Carr (1946, p. 10, 89-94) makes of realism, which has often been overlooked by realists, was in actuality a critique of determinism. In this respect, as Carr (1936) did elsewhere, he was in actuality arguing, in part, that war with Germany could be averted - it was not inevitable. The purpose here is not to launch an attack on Carr, however easy that with the benefit of hindsight may be (Fox, 1985). Rather the 
purpose here is to recognise that, to reflect on The Twenty Years' Crisis in terms of contemporary scholarship, there is a lot more Ikenberry (2008) than Mearsheimer (2010) in the text (not discounting the text's more radical/Marxist undertones and its attack on abstract liberal internationalism) (Cox, 1999, 2010).

After taking on board the revisionist literature on Carr, where does that leave us in terms of our understanding of The Twenty Years' Crisis and Carr's thought as a whole? More importantly, why call Carr a realist after all these (revisionist) years? After all, Jones (1998) observes that, although 'he eludes easy textbook classification', Carr 'was a realist of some kind or other' (p. 144); Cox concludes that Carr was a realist if of 'a very different sort' (Carr, 2001, p. xl); and Haslam (2002), perhaps in a less guarded moment, suggests that Carr was not dissatisfied with his machtpolitik image 'because he recognised the image to be not altogether inaccurate' (p. 200). In the next section I begin to unpack the ideas found in two texts, often overlooked by both realists and revisionists, which offer a clue as to why Carr's connection with realism is not only apt but is in fact even stronger given contemporary developments in the realist tradition.

\section{Restoration: Britain, German-Soviet Relations and the realist tradition}

I am referring here specifically to two texts produced by Carr on British, German and Soviet interwar diplomacy. Britain (1939) offered an explanation for British interwar policy that was sympathetic to both international (relative decline) and domestic (partisan politics) conditions. German-Soviet Relations (1951) outlined how these two nations were compelled by international conditions to seek a rapprochement during the interregnum, but significant attention was paid to pivotal individuals such as Gustav Stresemann, Germany's Foreign Minister throughout most of the 1920s, and Karl Radek, who amongst other things helped negotiate the Brest-Litovsk treaty and, from a prison cell, helped re-establish diplomatic links 
between the Soviet Union and Germany. The combined focus on both international factors (relative power) and domestic or unit-level factors (individuals and party politics) mean that these texts should, at the very least, be of interest to neoclassical realists. Indeed, in the third section of this paper I will make the case that this theoretical development in the realist literature makes Carr's (at least the Carr that wrote Britain and German-Soviet Relations) connection to realism more evident. Unfortunately, realists broadly tend to reduce Carr's contribution to The Twenty Years' Crisis, meaning that Britain and German-Soviet Relations have effectively been lost by realists (this point will be developed further in the subsequent section). The revisionist literature is also limited here in certain respects as the focus is instead on other texts in Carr's corpus (i.e. Conditions of Peace, Nationalism and After and What is History). ${ }^{1}$ If it is true that we must appreciate Carr's work as a whole to understand his political thought in toto (Wilson, 2001, p. 125), then this oversight is in need of correction.

To do so, it is first necessary to outline what is actually meant by realism. Typically, this is normally addressed by outlining some core theoretical assumptions e.g. state-centrism, the pervasiveness of anarchy and the centrality of power (Walt, 1997, p. 932). The problem with such theoretical constructs, however, is that they tend to impose 'upon a loose and fragmented assemblage of thought a degree of coherence which is arguably unjustified and unnecessary' (Haslam, 2002, p. 249). Rather than thinking about realism in terms of its theoretical assumptions, therefore, it is perhaps wiser to think about realism in terms of tradition. Traditions of thought are webs of beliefs and ideas which political thinkers inherit. They are, as Sterling-Folker (2009) notes, 'imagined communities of thought that provide a label and history for beliefs and practices' (p. 199). Following Haslam (2002), it is possible to conceive of the realist tradition in terms of four beliefs/ideas: raison d'état; the balance of power; the balance of trade; and geopolitics. ${ }^{2}$ 
The restoration of Britain and German-Soviet Relations will follow shortly, and at the same time it will draw from Haslam's beliefs/ideas to demonstrate the linkages between Carr's forgotten texts and the realist tradition. First, however, I shall attempt to pre-empt the criticism that may be raised should one follow this "key concepts" approach. Hall and Bevir (2014) contend that as traditions of thought are inherited and, equally importantly, that thinkers have agency to 'nurture, squander, build upon, or even reject' traditions, then traditions cannot be thought of as "having "fixed cores"' (p. 828). Core ideas, in other words, rise and fall in importance in term of the thinker/scholar and the context they inhabit. This view is repeated by Sterling-Folker (2009) who argues that traditions 'have no objective, natural core that determines what falls in and outside of their domains'; instead they are 'naturally incoherent and depend on creative, shifting, changing, and adaptive acts of will among those who subscribe to them' (p. 198). To start with no basic ideas makes the task of assessing the extent of a shared tradition problematic if not impossible, however. Moreover, recognising that shared themes exist in the realist tradition does not equate to accepting an essentialist understanding of these concepts, which is one of the chief arguments that Haslam (2002, p. 249) makes in his monograph. Following O'Driscoll's (2015, p. 2) invocation of Lloyd's bridgeheads of intelligibility, I use Haslam's four beliefs not as essentialist ideas but as a focal point around which to enable the comparison of Carr's thoughts in Britain and German-Soviet Relations and the realist tradition more broadly.

\section{The stretching out of hands across the ideological divide}

German-Soviet Relations was in effect a traditional diplomatic history. It was based on set of six lectures that Carr delivered as part of the Albert Shaw diplomatic history series in late 1950 and early 1951 (Haslam, 2000, pp. 148-149). The initial spur for the lectures and subsequent monograph was Carr's continuing work on his history of the Soviet revolution. In 
a letter to Isaac Deutscher Carr explained that the lectures and subsequent monograph were “"a sort of first draft"' (Haslam, 2000, p. 149) for his history's third volume. The principal theme was the manner in which these two outcasts from Versailles managed, owing to international conditions and despite of ideological differences, to reach two geopolitically critical alliances during the course of the interregnum. Carr (1951) termed it the 'stretching out of hands across the ideological barrier' (p. 48), which obviously fits rather snuggly with the idea of raison d'état.

The context to the book is obviously evident. Haslam (2000) provides the most complete overview (pp. 149-154). Specifically, we are looking at the early Cold War and Carr's hoped for middle ground - or balance - between the United States and Soviet Russia as well as his deference to Soviet Russia. The former runs through much of German-Soviet Relations, specifically the chapter on Stresemann's diplomatic skill - what Carr (1951) referred to as his skill for exercising 'a great economy of truth' (p. 89) - for balancing between east and west. The connection with Carr's own proclivities is obvious. Moreover, German-Soviet Relations touches upon the pacification of the Soviet Union (at least in terms of foreign policy). Carr (1951) noted, as an example, the effects of the 1921 New Economic Policy, which stimulated "the development of "normal relations" between Soviet Russia and the capitalist countries, and [relegated] international revolution to the background as an element of Soviet diplomacy' (p. 39). In effect, this meant that Soviet policy toward Germany was dictated more by raison d'état and less by revolutionary fervour, meaning that the failure of the aborted Moscow-backed Communist uprising in October 1923 was the last attempt at fomenting socialism in Germany. 'Never again were the expectations of an early revolution in Germany allowed to override the normal considerations of foreign policy', wrote Carr (1951), 'Never again would Comintern pursue an independent policy of its own' (p. 76). 
It should be evident from the above that raison d'état was central to Carr's diplomatic history of German and Soviet relations between the wars. Balance of power, balance of trade and geopolitics were equally critical. Carr explained the Rapallo treaty in terms of relative power. 'The time would come in the nineteen-thirties when Germany could afford to abandon the policy of the balance', wrote Carr (1951), 'and by that time Soviet Russia was also strong enough to make a choice between Germany and the western allies' (p. 89). The implication, in other words, was that the 1920s rapprochement was borne form relative power. However, it was not simply relative power that was influencing Russian and German diplomacy at this juncture. German-Soviet Relations also documented the economic structures which necessitated the shifting relationship. Matters of trade were crucial to Germany's recovery from the First World War (Carr, 1951, pp. 78-79). Moreover, the increasing centralization of German industry coupled with Germany's exclusion from the capitalist powers helped facilitate the turn eastward in terms of market access (Carr, 1951, pp. 12-13). At the same time, the pacification of Soviet revolutionary aims in terms of Lenin's New Economic Policy was, for Carr (1951, pp. 38-39), a product of economic interests and realities. His analysis in German-Soviet Relations equally centred in on geopolitics, particularly with regard to Germany. Take his discussion of the Rapallo treaty as an example. For Carr (1951), it 'put Germany back into the position which geography had assigned to her of being able to manoeuvre on both her flanks, alternately seeking the support of the west against the easy and the east against the west' (p. 68). Germany's geographic position, in other words, meant that the country was compelled to seek good relations with both, but especially its eastern neighbour. 


\section{Concerned not with ideology but with power politics}

Britain, according to the author's preface, aimed to provide a 'critical but not unsympathetic survey of British foreign policy' (Carr, 1939, p. viii) between the wars. Although published in the same year as the first edition of The Twenty Years' Crisis, Britain is radically different in terms of its gestation period. Whereas The Twenty Years' Crisis was conceived of in 1937 and drew from ideas dating back to Carr's time in Soviet Russia and before (Wilson, 2004, p. 185), Britain was completed in 1939 after Munich. Like German-Soviet Relations, however, the text was littered with phrases immediately appealing to realist ears. Focusing in on British national interests and the German question specifically, Carr again drew from raison d'état. Although recognising that partisan politics had significantly shaped British policy toward Soviet Russia since its revolution, he nevertheless observed that 'since [1934] policy has primarily been concerned not with ideologies but with what are commonly called "power politics"' - in effect the German question (Carr, 1939, p. 147).

The context - or what Carr (1964) would have called the 'buzzing' (p. 23) - is again evident. Britain is, in many respects, Carr's mea culpa as Cox notes (Carr, 2001, p. xxvii). Having outlined Britain's European strategy as ensuring the prevention of a continental hegemon (Carr, 1939, p. 124), Carr's depiction of Germany in the closing passages of text, namely a state intent on 'the brutal domination' (p. 196) of Europe, is in obvious contrast to The Twenty Years' Crisis. In many respects, however, Carr used Britain to defend appeasement in terms of inter alia relative power and capabilities. As he observed: 'the armament situation made a policy of conciliation the only practical one' (Carr, 1939, p. 176). The context, i.e. the developing conflict with Nazi Germany and Carr's own ideological proclivities, also explain the étatist understanding democracy underpinning Britain (Jones, 1998, p. 152), which again demonstrates the prevalence of raison d'état in Britain. 
Geopolitics, relative power and balance of trade were also utilised by Carr in Britain. Britain, as already noted, focused on relative decline and the manner in which this constrained Britain's capacity to act like a hegemon (Carr, 1939, pp. 21-22). Moreover, Carr (1939) also wrote that foreign policy 'is always dependent on the possession of military strength, or rather, on the ratio between the military strength of one's own country and that of others' (p. 17). Underpinning Britain's relative decline at this juncture was relative economic decline. Carr (1939) noted that the loss 'of economic power, whether absolute or relative, means loss of political power' (p. 26). In turn, Britain's capacity for intervention became less (Carr, 1939, p. 21). Moreover, relative economic decline also explained Britain's move toward a preventive, status quo orientated grand strategy (Carr, 1939, pp. 26-27). Additionally, Carr clearly believed that British policy was a product of its geographical location. Owing to its geographical position, Carr (1939, p. 34) contended that Britain was drawn into the European balance of power whenever circumstances necessitated it. In fact, he went as far as to suggest that Britain's geographical location 'determines the nature of her [sic] European policy' (Carr, 1939, p. 124). He was not entirely consistent here with regard to the geopolitical determinism, however. Earlier in the text, as an example, he concluded that Britain's role as a world as opposed to a European power was borne not from geography but from Britain's specific development as an industrial-imperialist power (Carr, 1939, p. 35).

\section{Contemporary reconstruction: Britain, German-Soviet Relations and}

\section{neoclassical realism}

The last point - a structure, i.e. geography, conditions but does not determine a state's policy or behaviour - instinctively leads to the possibility of a conversation between Britain, German-Soviet Relations and neoclassical realism. Considering Carr's lost work in light of neoclassical realism is apt because neoclassical realism has been argued to be 'the only game 
in town for the next and the current generation of realists' (Schweller, 2003, pp. 344-345). Given this, it is unsurprising that neoclassical realism is firmly established in the literature so only a cursory introduction is necessary here (e.g. Lobell et al, 2009; Toje and Kunz, 2012a). Neoclassical realism seeks to explain policy rather than international outcomes. It does so by drawing from both the parsimony and rigour of structural realism and the diplomatic insights drawn from classical realism (Taliaferro et al, 2009, p. 4). It is a contingent theory in that it argues that the external structure is crucially influential in shaping a state's conduct. Yet, internal dynamics (i.e. institutional capacities, the intellectual climate and bureaucratic and individual actors) are equally critical in terms of policy action and inaction. This is because they act as a transmission belt through which structural constraints and incentives are perceived, understood and acted upon (Rose, 1998, p. 158). This focus is logical. After all, 'any specific foreign policy decision...is contingent on domestic and individual unit-level factors' (Lobell et al, 2015, p. 157).

In order to assess the similarities and indeed points of departure between neoclassical realism and Britain and German-Soviet Relations it is necessary to render some core assumptions of neoclassical realism. First, neoclassical realists typically contend that the state's principal priority is security in response to threat. As Dueck (2009) explains, neoclassical realism 'begins by positing that state officials inevitably have some conception of the national interest in the face of potential external threats' (p. 146). Second, neoclassical realism works with a "“top-down" conception of the state' (Taliaferro et al, 2009, p. 25). This means that the state - or more appropriately the executive charged with making a state's foreign policy - is driven primarily by systemic incentives and constraints. Accordingly, the executive 'is potentially autonomous from society' (Taliaferro et al, 2009, p. 25). Despite this, however, the executive is constrained by the domestic political environment, and factors such as public opinion, societal interest groups and other bureaucratic actors create variation 
in how states respond to external pressure (Ripsman, 2009, pp. 171-174). Third, neoclassical realists, drawing from Rose's (1998, p. 158) imperfect transmission belt analogy, highlight the importance of subjective perceptions. As Taliaferro and Wishart (2014) observe, leaders "define "national interests" based upon their subjective assessments of the international distribution of power and other states' intentions' (p. 48). Fourth, neoclassical realists posit that over the long-term the policies a state pursues will reflect structural constraints and incentives, namely the distribution of capabilities (Taliaferro et al, 2009, p. 4). This is because the "position of the state in the international system defines the boundaries of the possible range of policies it can adopt in the long term' (Devlen and Özdamar, 2009, p. 144). However, neoclassical realists believe 'that the link between capabilities and intentions is a starting point and not a rigid causal relationship' (Juneau, 2015, p. 21). The international structure, in other words, conditions but does not determine state behaviour (Schweller, 1998, p. 3).

These ideas are evident in both Britain and German-Soviet Relations. Take the first principal, as an example. In Britain, Carr (1939) concluded that security is chief: 'The prudent statesmen', he wrote, 'must...not pursue a policy which is likely to expose his country to war against equal or superior odds' (p. 17). Moreover, Carr (1951, pp. 134-136) explained Stalin's controversial non-aggression pact with Nazi Germany on the basis of the primacy of security (if the Soviet Union could not rely on the Western nations to balance the threat, which is what Stalin believed at that juncture, then the non-aggression pact could purchase immunity from Germany). Carr's (1939, pp. 29-30, 68-69; 1951, pp. 4-13) discussions of the British state, particularly its relationship to and independence from capitalist interests, and the German state, specifically its capacity to balance competing groups vying for an eastern and western outlook, reflect the second neoclassical realist principle outlined above. The importance of perception and misperception in terms of threat 
and others' intentions are also evident in Britain and German-Soviet Relations (Carr, 1939, p. 192; 1951, p. 114). Finally, in many places Carr's lost texts illustrated the idea that the external environment conditioned but did not determine behaviour. This is best evidenced in the agency he attributed to Hitler and William II in acting contra to Germany's geographical and historical traditions (Carr, 1951, p. 1). The same idea was also evident in the manner in which shared norms and culture meant that increasing American power was less threatening to Britain than increasing German power (Carr, 1939, pp. 43-44).

If the analysis presented here is correct, then the Carr that wrote Britain and GermanSoviet Relations is a stone's throw away from the leading realist approach in IR. At face value, this is hardly surprising as, inter alia, Carr is typically depicted as a leading figure that neoclassical realists wish to draw from (Taliaferro et al, 2009, p. 4). What is particularly puzzling, however, is that neoclassical realists (as realists tend to do) generally reduce Carr's contribution to The Twenty Years' Crisis. Unfortunately, as the revisionist literature has shown, and this paper is in agreement with, this text's association with realism is dubious at best. As neoclassical realists increasingly turn toward the grand strategies of the great powers during the wars (Taliaferro et al, 2012), the neglect of Carr's writings in this area is puzzling if not reflective of realism's weak historical consciousness. As a corrective, greater recognition should be given to Britain and German-Soviet Relations in the neoclassical canon instead of The Twenty Years' Crisis. ${ }^{3}$

There are two reasons why this re-engagement could prove fruitful. First, situating Carr's forgotten texts in the neoclassical realist canon would exploit the difference between competing variants of neoclassical realism. Neoclassical realism is increasingly in danger of becoming Waltzian neorealism plus. In fact, neoclassical realism has been argued to be a logical extension of neorealism because it 'vindicate[s] Waltz [rather than] undermin[ing] him' (Rathbun, 2008, p. 296). This is because neoclassical realists typically reduce the 
external environment to anarchy and the distribution of capabilities, much as neorealism does (Schmidt and Juneau, 2012, p. 69). This is why the moniker neo-neorealism as opposed to neoclassical realism is apt for a lot self-conscious neoclassical realist work (Toje and Kunz, 2012b, p. 8). However, the external constraints and incentives which shape a country's foreign policy do not stop at neorealism's edge (Buzan et al, 1993, pp. 29-33). The realism in Britain and German-Soviet Relations, which pointed to geography, history, relative power, ideological affinity, technology and international institutions as important conditioners of a state's diplomatic conduct, offers a more extensive understanding of the external pushes and pulls on a country's behaviour. This is important because the emergence 'of a distinctly European realist school which draws on the roots of the historical, European tradition' has recently been observed (Toje and Kunz, 2012b, p. 10). Unfortunately, only one of the chapters in this collection, Battisela's (2012) discussion of Raymond Aron, seems explicitly concerned with employing classical works and authors to exploit the difference between the European and North American variants of neoclassical realism (Berenskoetter's and Quinn's (2012) chapter points to Carr, but makes the typical error of reducing Carr's realism to The Twenty Years' Crisis). The value-added worth of the recovery of some of Carr's forgotten work rests in its capacity for acting as a base for broadening our understanding of neoclassical realism beyond neorealism.

Second, and related, the turn to Britain and German-Soviet Relations could potentially overcome some of the tensions identified in marrying the parsimony of Waltz's determinative structure with a more contingent and empirically richer approach to foreign policy analysis. Quinn (2013) contends that neoclassical realism's focus on an ever-expanding set of unitlevel variables puts neoclassical realism on a 'collision course' (p. 164) with its intellectual baseline. His solution to this dilemma is to argue that, rather than being complementary to neorealism, neoclassical realism's bolder and more authentic contribution rests in its capacity 
for offering a challenge to neorealism (that is, by showing where and how states have, over the long-term, eschewed system imperatives and escaped systemic punishment) (Quinn, 2013, pp. 176-177). Although provocative, the fork-in-the-road identified - neoclassical realism as either a complement to or a reaction against neorealism - continues to reproduce a Waltzian-centric understanding of realism, which tends to overlook the pathological influence that Waltz had on realism (Wohlforth, 2011). Yes, utilising Carr's classical works on great power interwar diplomacy may produce more classical than neoclassical insights. However, this criticism only holds weight if one adopts a pejorative stance toward classical realism. If, on the other hand, one is more welcoming of a classical realist revival (Rynning and Ringsmose, 2008), then there is little to fear in turning to more traditional works.

\section{Conclusion}

Revisionist historiography has forced the discipline to reconsider many of its supposed foundational truths. E.H. Carr, arguably a pivotal thinker in the history of international political thought, has been caught up in this development. The revisionist turn has resulted in the questioning of Carr's association with the realist tradition. Typically, realists, pointing to specific aspects of The Twenty Years' Crisis, answer yes to the question of whether Carr was a realist. Drawing from Carr's thought more widely, revisionists have challenged this depiction and, in turn, offered a more nuanced and ultimately sophisticated understanding of Carr.

In terms of The Twenty Years' Crisis there is little inaccurate with the revisionist literature. In fact, recovering Britain and German-Soviet Relations - as was done above further bolsters the revisionist case that The Twenty Years' Crisis has been poorly understood in some quarters. At the same time, however, Britain and German-Soviet Relations serve to highlight the incompleteness of the revisionist literature. Pointing to Carr's more overt 
imbibing of the realist tradition in these texts suggests that the revisionists have overlooked a more hard-nosed realism - a realism that did not appear as naked as say in The Twenty Years' Crisis for example. Where does that leave our understanding of Carr? Given that the progressive aspects (the what could or even should be) of say The Twenty Years' Crisis, Conditions of Peace, Nationalism and After and What is History jar with the historicalempirical work (the what was) of Britain and German-Soviet Relations, is Carr, to borrow from Humphreys' (2013) work on Waltz, a 'theorist divided against himself' (p. 864)? This hinges on whether we expect a scholar's work to remain consistent over time. For Carr (1964) this was not the case: as the 'historian himself is in flux', just like not being able to step into the same river twice, two exact same 'books cannot be written by the same historian' (p. 42).

This exercise has more relevance than simply refining our understanding of Carr's contribution to IR theory. Indeed, the analysis presented above suggests close parallels between Britain, German-Soviet Relations and neoclassical realism. Some might say that this is hardly surprising; after all, Carr is one of the many classical authors that neoclassical realists seek to draw influence from. However, typically (if not rather puzzlingly) they only refer to The Twenty Years' Crisis, which is at best loosely connected to the realist tradition. A more fruitful starting point for thinking about Carr and neoclassical realism rests in Britain and German-Soviet Relations. At the very least, the more in-depth understanding of the pushes and pulls on a country's foreign policy developed in these texts would serve as a useful tool for those seeking to carve out a distinctly European variant of realist foreign policy analysis. 


\section{Acknowledgements}

An earlier iteration of this paper was presented at the International Relations Group, School of Social and Political Sciences, University of Glasgow. The author would like to thank the following for their comments and suggestions: Andrew Hom, Cian O’Driscoll, Georgios Karyotis, Ian Paterson, Kelly Kollman, Louis Bujnoch and Ty Solomon.

\section{Notes}

1 Generally speaking, the revisionist literature has tended to focus on these three texts along with The Twenty Years' Crisis. There are always exceptions to rules. Although providing a limited account of Britain, Haslam (2002, p. 149) notes that in German-Soviet Relations 'Carr the realist was in the ascendant'. Jones (1998, chapter 7), in contrast, makes less use of German-Soviet Relations (although he does use a quotation from it to subtitle his monograph) and more of Britain in terms of building the case for Carr as a pragmatic realist. Molloy (2013) also draws from Britain in order to illuminate upon Carr's advocacy of appeasement. This paper, while influenced by these works, develops the case further by situating Britain and German-Soviet Relations alongside contemporary developments in the realist tradition, i.e. neoclassical realism.

2 Raison d'état refers to that 'the belief that, where international relations are concerned, the interests of the state predominate over all other interests and values' (Haslam, 2002, p. 17). Although the balance of trade may be the most problematic category in Haslam's tour d'horizon, given that it may be awkward to think of the many political economists he refers to as belonging to one tradition, at its minimum it refers to the principle that 'wealth [is] the precondition of power' (Haslam, 2002, p. 128). Geopolitics, in contrast, emphasises the manner in which a state's geographic position constraints and incentivises its behaviour (Haslam, 2002, p. 162). Haslam's (2002, pp. 90-91) definition of the balance of power broadly follows Hume, i.e. natural equilibrium. This understanding of the balance of power has been called into question empirically (Kaufman et al, 2007). I, therefore, utilise the balance of power in terms of viewing it as a state of affairs which necessarily influences state behaviour. I draw from Wohlforth's (1994) observation that realists view state behaviour as an 'adaption to external constraints conditioned by changes in relative power' (p. 96). 
3 It should be noted that there are epistemological differences between Britain, German-Soviet Relations and neoclassical realism. Whilst the latter tended toward a traditionalist history, contemporary neoclassical realists lean toward a history without historicism where history is utilised to verify, refine and refute theoretical and hypothetical propositions. For this argument with regard to Carr's later diplomatic histories of the Soviet Union and their relationship to realism see Smith (forthcoming).

\section{References}

Ashworth, L. (2014) A History of International Thought: From the Origins of the Modern State to Academic International Relations. London: Routledge.

Babík, M. (2013) Realism as critical theory: The international thought of E.H. Carr. International Studies Review 15(4): 491-514.

Battisela, D. (2012) Raymond Aron: A neoclassical realist before the term existed. In: A. Toje and B. Kunz (eds.) Neoclassical Realism in European Politics. Manchester: Manchester University Press, pp. 117-132.

Behr, H. and Molloy, S. (2013) Realism reconsidered: New contexts and critiques. International Politics 50(6): 736-738.

Bell, D.S.A. (2001) International relations: The dawn of a historiographical turn. British Journal of Politics and International Relations 3(1): 115-126.

Bell, D.S.A. (2009) (ed.) Political Thought and International Relations: Variations on a Realist Theme. Oxford: Oxford University Press.

Berenskoetter, F. and Quinn, A. (2012) Hegemony by invitation: Neoclassical realism, soft power and US-European relations. In: A. Toje and B. Kunz (eds.) Neoclassical Realism in European Politics. Manchester: Manchester University Press, pp. 214233.

Booth, K. (1991) Security in anarchy: Utopian realism in theory and practice. International Affairs 67(3): 527-545. 
Buzan, B., Jones, C. and Little, R. (1993) The Logic of Anarchy: Neorealism to Structural Realism. New York: Columbia University Press.

Carr, E.H. (1936) Public opinion as a safeguard of peace. International Affairs 15(6): 846862.

Carr, E.H. (1939) Britain: A Study of Foreign Policy from the Versailles Treaty to the Outbreak of War. London: Longmans Green.

Carr, E.H. (1946[1939]) The Twenty Years' Crisis, 1919-1939: An Introduction to the Study of International Relations. 2nd edition. New York: Harper \& Row.

Carr, E.H. (1951) German-Soviet Relations between the Two World Wars, 1919-1939. Baltimore: John Hopkins Press.

Carr, E.H. (1964[1961) What is History? London: Penguin.

Carr, E.H. (2001[1939]) The Twenty Years' Crisis, 1919-1939: An Introduction to the Study of International Relations. Edited by M. Cox. London: Macmillan.

Cox, M. (1999) Will the real E.H. Carr please stand up? International Affairs 75(3): 643-653.

Cox, M. (ed.) (2004) E.H. Carr: A Critical Appraisal. London: Palgrave Macmillan.

Cox, M. (2010) E.H. Carr and the crisis of twentieth-century liberalism. Millennium Journal of International Studies 38(3): 523-533.

Cox, M. (2012) Foreword. In: B. Schmidt (ed.) International Relations and the First Great Debate. London: Routledge, pp. xii-xiv.

Devlen, B. and Özdamar, Ö. (2009) Neoclassical realism and foreign policy crises. In: A. Freyberg-Inan, E. Harrison and P. James (eds.) Rethinking Realism in International Relations. Baltimore: John Hopkins Press, pp. 136-163.

Dueck, C. (2009) Neoclassical realism and the national interest: Presidents, domestic politics, and major military interventions. In: S.E. Lobell et al (eds.) Neoclassical Realism, the State, and Foreign Policy. Cambridge: Cambridge University Press, pp. 139-170. 
Dunne, T., Cox, M. and Booth, K. (eds.) (1998) The Eighty Years' Crisis: International Relations, 1919-1999. Cambridge: Cambridge University Press.

Evans, G. (1975) E.H. Carr and International Relations. British Journal of International Studies 1(1): 77-97.

Fox, W.T.R. (1985) E.H. Carr and political realism: Vision and revision. Review of International Studies 11(1): 1-16.

Hall, I. and Bevir, M. (2014) Traditions of British international thought. The International History Review 36(5): 823-834.

Haslam, J. (2000) The Vices of Integrity: E.H. Carr, 1892-1982. London: Verso.

Haslam, J. (2002) No Virtue Like Necessity: Realist Thought in International Relations since Machiavelli. New Haven: Yale University Press.

Howe, P. (1994) The utopian realism of E.H. Carr. Review of International Studies 20(3): $277-297$.

Humphreys, A.R.C. (2013) 'Waltz and the world: Neorealism as international political theory. International Politics 50(6): 863-879.

Ikenberry, G.J. (2008) The rise of China and the future of the west: Can the liberal system survive. Foreign Affairs 87(1): 23-37.

Johnston, W. (1967) E.H. Carr's theory of International Relations. The Journal of Politics 29(4): 861-884.

Jones, C. (1998) E.H. Carr and International Relations: A Duty to Lie. Cambridge: Cambridge University Press.

Juneau, T. (2015) Squandered Opportunity: Neoclassical Realism and Iranian Foreign Policy. Stanford: Stanford University Press.

Kaufman, S.J., Little, R. and Wohlforth, W.C. (2007) The Balance of Power in World History. London: Palgrave Macmillan. 
Kostagiannis, K. (2013) Mind the gap between nationalism and International Relations: Power and the nation-state in E.H. Carr's realism. International Politics 50(6): 830845.

Linklater, A. (1997) The transformation of political community: E.H. Carr, critical theory and International Relations. Review of International Studies 23(3): 321-338.

Lobell, S.E., Ripsman, N.M. and Taliaferro, J.W. (eds.) (2009) Neoclassical Realism, the State, and Foreign Policy. Cambridge: Cambridge University Press.

Lobell, S.E., Jesse, N.G. and Williams, K.P. (2015) Why do secondary states choose to support, follow or challenge? International Politics 52(2): 146-162.

Mearsheimer, J.J. (2005) E.H. Carr vs idealism: The battle rages on. International Relations 19(2): 139-152.

Mearsheimer, J.J. (2010) The gathering storm: China's challenge to US power in Asia. The Chinese Journal of International Politics 3(4): 381-396.

Molloy, S. (2013) Spinoza, Carr, and the ethics of The Twenty Years' Crisis. Review of International Studies 39(2): 251-271.

Nishimura, K. (2011) E.H. Carr, Dostoevsky, and the problem of irrationality in modern Europe. International Relations 25(1): 45-64.

O’Driscoll, C. (2015) Rewriting the just war tradition: Just war in classical Greek political thought and practice. International Studies Quarterly 59(1): 1-10.

Quinn, A. (2013) Kenneth Waltz, Adam Smith and the limits of science: Hard choices for neoclassical realism. International Politics 50(2): 159-182.

Rathbun, B. (2009) A rose by any other name: Neoclassical realism as the logical and necessary extension of structural realism. Security Studies 17(2): 294-321. 
Ripsman, N.M. (2009) 'Neoclassical realism and domestic interest groups. In: S.E. Lobell et al (eds.) Neoclassical Realism, the State, and Foreign Policy. Cambridge: Cambridge University Press, pp. 170-193.

Rose, G. (1998) Neoclassical realism and theories of foreign policy. World Politics 51(1): $144-172$.

Rynning, S. and Ringsmose, J. (2008) Why Are revisionist states revisionist? Reviving classical realism as an approach to understanding international change. International Politics 45(1): 19-39.

Schmidt, B. (ed.) (2012) International Relations and the First Great Debate. London: Routledge.

Schmidt, B. and Juneau, T. (2012) Neoclassical realism and power. In: A. Toje and B. Kunz (eds.) Neoclassical Realism in European Politics. Manchester: Manchester University Press, pp. 61-78.

Schweller, R.L. (1998) Deadly Imbalances: Tripolarity and Hitler's Strategy of World Conquest. New York: Columbia University Press.

Schweller, R. L. (2003) The progressiveness of neoclassical realism. In: C. Elman and M. Elman (eds.) Progress in International Relations Theory: Appraising the Field. Cambridge: MIT Press, pp. 311-348.

Smith, K. (2016) The realism that did not speak its name: E.H. Carr's diplomatic histories of the twenty years' crisis. Review of International Studies forthcoming.

Steele, B. (2013) Context and appropriation: The risks, benefits and challenges of reinterpretive expression. International Politics 50(6): 739-752.

Sterling-Folker, J. (2009) Forward is as forward does: Assessing neoclassical realism from a traditions perspective. In: A. Freyberg-Inan, E. Harrison and P. James (eds.) 
Rethinking Realism in International Relations. Baltimore: John Hopkins Press, pp. $191-218$.

Taliaferro, J.W., Lobell, S.E. and Ripsman, N.M. (2009) Introduction: neoclassical realism, the state, and foreign policy. In: Lobell, S.E. et al (eds.) Neoclassical Realism, the State, and Foreign Policy. Cambridge: Cambridge University Press, pp. 1-41.

Taliaferro, J.W., Ripsman, N.M. and Lobell, S.E. (eds.) (2012) The Challenge of Grand Strategy: The Great Powers and the Broken Balance between the World Wars. Cambridge: Cambridge University Press.

Taliaferro, J.W. and Wishart, R.W. (2014) Neoclassical realism: Domestic opportunities for great power intervention. In: J. Sterling-Folker (ed.) Making Sense of International Relations Theory. Boulder: Lynne Reinner, pp. 47-66.

Thompson, K.W. (1980) Masters of International Thought. Baton Rouge: Louisiana State University Press.

Toje, A. and Kunz, B. (eds.) (2012a) Neoclassical Realism in European Politics. Manchester: Manchester University Press.

Toje, A. and Kunz, B. (2012b) Introduction: Neoclassical realism in Europe. In: A. Toje and B. Kunz (eds.) Neoclassical Realism in European Politics. Manchester: Manchester University Press, pp. 1-16.

Walt, S.M. (1997) The progressive power of realism. American Political Science Review 91(4): 931-935.

Williams, M.C. (ed.) (2007) Realism Reconsidered: The Legacy of Hans Morgenthau in International Relations. Oxford: Oxford University Press.

Wilson, P. (2001) Radicalism for a conservative purpose: The peculiar realism of E.H. Carr. Millennium - Journal of International Studies 30(1): 123-136. 
Wilson, P. (2004) Carr and his early critics: Responses to The Twenty Years' Crisis, 19391946. In: M. Cox (ed.) E.H. Carr: A Critical Appraisal. London: Palgrave Macmillan, pp. 165-197.

Wilson, P. (2012) 'Where are we now in the debate about the first great debate. In: B. Schmidt (ed.) International Relations and the First Great Debate. London: Routledge, pp. 133-151.

Wohlforth, W.C. (1994) Realism and the end of the cold war. International Security 19(3): $91-129$.

Wohlforth, W.C. (2011) Gilpinian realism and International Relations. International Relations 25(4): 499-511. 